\title{
FENOMENA LAHN \\ DALAM RITUAL IBADAH
}

\author{
H.R.Taufiqurrochman \\ Fakultas Humaniora dan Budaya, Jurusan Bahasa dan Sastra Arab
}

\begin{abstract}
One of the language characteristic is that the language is composed of a certain sound system that is distinctive to each other. Al-Qur'an that is revealed in Arabic should be articulated appropriately and accurately in order to avoid mistakes, explicitly or implicitly. Lahn is called as solecism in linguistics and catachresis in literature. According to tajwid science (Al-Qur'an Phonology), Lahn is defined as mis pronunciation in reading Al-Qur'an. That is why the readers should be able to learn more about tajwid. It is important to avoidmaking lahn that will change the meaning of the Holly Al-Qur'an. This article is aimed at describing lahn phenomenon that appears in religious activities such as adzan, iqamat, tahlil, talbiyah, and praying.
\end{abstract}

Key words: lahn, tajwid science, al-Qur'an phonology

\section{Pengertian Lahn}

Lahn menurut bahasa berarti salah. Dalam linguistik, lahn sering dikenal dengan istilah solecism yang berarti kesalahan gramatikal yang dialami seseorang pada saat berujar atau membaca. Dalam kajian sastra, lahn diartikan catachresis, yaitu kesalahan dalam menggunakan sebuah kata metafora (majazi) dan realita (hakiki). (Wahbah, 1984:316) Namun, sebelum ilmu bahasa dan sastra berkembang pesat, istilah lahn telah dikenal sejak zaman Nabi Muhammad SAW, terutama dalam hubungannya dengan tilawah al-Qur'an. Lahn dipahami sebagai sebuah kesalahan dalam membaca al-Qur'an, baik kesalahan itu berimplikasi terhadap perubahan makna ayat maupun tidak. Jadi, lahn lebih sering dikenal sebagai kesalahan ujar menurut tolak ukur bidang ilmu tajwid atau fonologi al-Qur'an. Sebuah ilmu yang pertama kali lahir setelah lahirnya Islam. (Al-Habasy, 1987:55). 


\section{Urgensi Lahn}

Melihat implikasi lahn, terutama dalam membaca al-Qur'an yang bisa berakibat kepada merubah makna ayat-ayat suci, maka belajar ilmu tajwid hukumnya fardlu kifayah. Sedangkan mengaplikasikan tajwid, hukumnya fardlu ain bagi setiap muslim. (Husni, 1994:51). Al-Ghazali me-mandang ilmu tajwid sebagai mutammimaat (ilmu pelengkap) yang secara kolektif, hukumnya fardlu kifayah (al-Ghazali, 1991:I/28). Hal yang sama diungkapkan Ibnu Ghazi. Menurutnya, hukum mengetahui ilmu tajwid atau fonologi al-Qur'an adalah fardlu kifayah, tapi mengamalkannya adalah fardlu 'ain bagi setiap orang Islam yang mukallaf, baik laki-laki maupun perempuan. Hukum ini berdasarkan dalil dari Al-Qur'an, as-Sunnah, dan ijma' (Nasr, 7).

\section{Macam-macam Lahn}

Dalam kajian ilmu tajwid, lahn berarti kesalahan atau penyimpangan yang terjadi pada artikulasi/pengucapan ayat-ayat al-Qur'an (Utsman, 1994:10). Seseorang yang salah atau tidak tepat dalam membaca al-Qur'an dan bacaannya menyimpang dari kaidah ilmu tajwid, maka ia disebut lahin. Lahn atau kesalahan bertajwid dibagi 2 (dua) macam; yaitu: (1) Lahn Jali (kesalahan yang jelas) dan (2) Lahn Khafi (kesalahan yang samar)

\section{Lahn Jali (kesalahan yang jelas)}

Lahn Jali adalah kesalahan yang bisa diketahui oleh semua orang, baik ulama (baca: qari) maupun orang awam. Salah satu ciri lahn jali adalah kesalahan yang dapat mempengaruhi atau merubah makna. Kesalahan tersebut adakalanya terdapat pada i'rab, huruf, jumlah, ataupun pada waqaf.

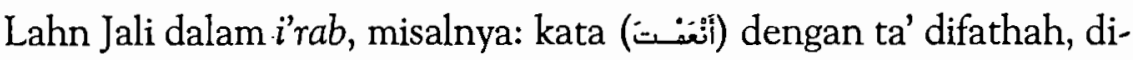

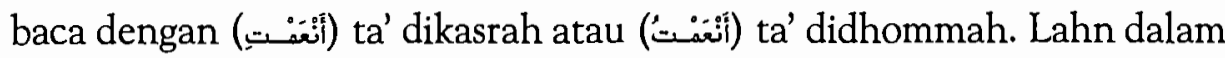

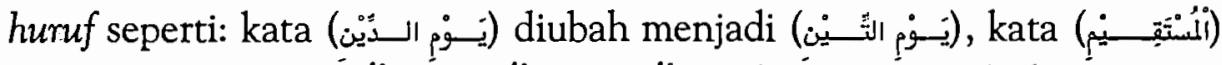

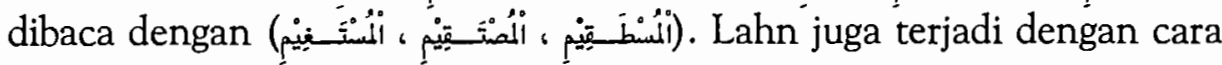

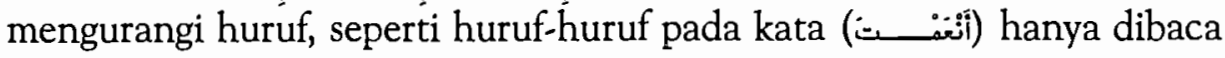

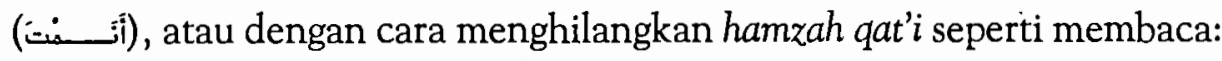

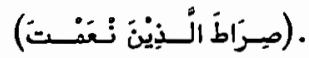


Lahn Jali hukumnya haram. Jadi, seorang qari' atau pembaca al-Qur'an berdosa bila melakukan lahn jali, baik ia tahu maupun tidak tahu kalau bacaannya yang salah itu dapat merubah makna atau merubah i'rab. Lahn Jali, bila terdapat dalam bacaan surat al-Fatihah, dapat membatalkan shalat bagi orang yang mampu membaca al-Fatihah secara bertajwid. Sedangkan bagi orang ummi (yang tidak mampu lagi bertajwid dengan baik sekalipun ia telah terus belajar), maka menurutpendapat yang shahih, sholatnya tetap sah sebab ia dihukumi madzur. Namun, jika si ummi menjadi imam dan makmumnya seorang qari, maka hanya shalat si ummi yang tetap sah. Sedangkan shalat si qari yang bermakmum kepada si ummi dihukumi batal. (Utsman, 54). Dalam keadaan semacam ini, si qari' lebih berhak menjadi imam daripada si ummi.

\section{Lahn Khafi (kesalahan yang samar)}

Lahn Khafi adalah kesalahan yang terdapat pada lafadz dan tidak merubah makna. Lahn Khafi hanya dapat diketahui para qari' yang mampu bertajwid dengan baik. Lahn Khafi terbatas.pada kesalahan artikulatif yang tidak sesuai dengan makhraj (out-put), sifat huruf dan beberapa hukum tajwid seperti: mad, ghunnah, idgham, bacaan miring dan sebagainya. Con-

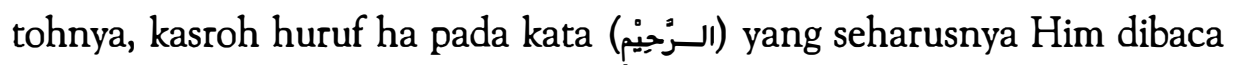

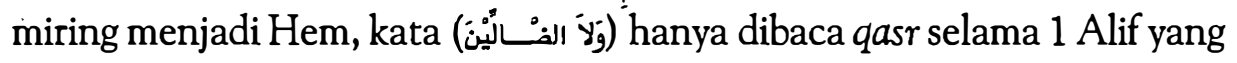
semestinya dibaca panjang (mad) selama 3 Alif, dan sebagainya.

\section{Faktor Penyebab Lahn}

Faktor utama penyebab munculnya lahn bagi masyarakat non-Arab (Indonesia) adalah konstrastif sistem fonetik antara bahasa setempat dengan bahasa Arab. Misalnya, konsonan bahasa Arab terdiri dari 28 konsonan dan bahasa Indonesia hanya berjumlah 24 konsonan. Ada beberapa bunyi bahasa Arab yang tidak terdapat dalam bunyi bahasa Indonesia (seperti: $\tau^{-\varepsilon-\omega-\omega-b-b-j)}$ dan hal ini rentan menimbulkan kesalahan penuturan terhadap bunyi-bunyi itu. Sebaliknya, ada juga bunyi bahasa Indonesia yang tidak terdapat dalam bunyi bahasa Arab, (seperti:ng ny c) sehingga sering muncul penyimpangan dari huruf (ع) dituturkan (ng). 
Terkadang ada bunyi yang sama-sama ada dalam kedua bahasa, tapi mempunyai perbedaan sifat dan makhraj yang pasti mengakibatkan lahn. (Nasution, 2006:20)

\section{Lahn dan Perubahan Makna}

Akibat negatif yang ditimbulkan dari lahn adalah perubahan makna. Tanpa penguasaan aplikatif terhadap ilmu tajwid, seseorang pasti melakukan kesalahan (lahn). Beberapa bentuk perubahan makna karena lahn yaitu:

1- Perubahan satu segmen dari bahasa Arab, seperti perubahan kata

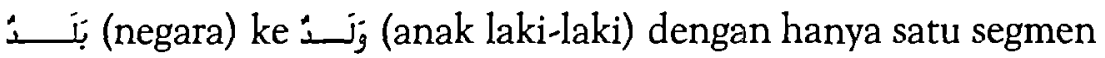
(ب) menjadi (G), walaupun segmen lainnya tidak mengalami perubahan.

2- Perubahan peletakan penggalan kata, seperti perubahan dari kata

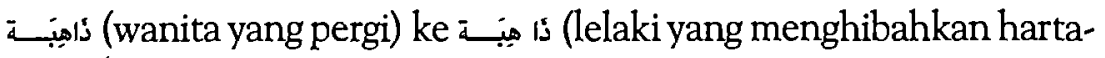
nya). Walaupun semua segmennya sama, akan tetapi karena perbedaan letak tekanan dalam kata tersebut berbeda, maka maknanya juga berbeda.

3- Perubahan makna kata atau kalimat karena perubahan panjang pendek, seperti kata مَ tanpa mad yang berarti hujan ke kata dengan mad pada (b) yang berarti lapangan udara. (Nasution, 2006: 20)

Selain di atas, masih banyak kemungkinan terjadinya perubahan makna kata atau kalimat karena perbedaan. sistem fonetik. Realitas ini yang me-nunjukkan urgensi ilmu tajwid sebagai pengetahuan yang harus dikuasai setiap umat Islam yang senantiasa berinteraksi dengan al-Qur'an dan bahasa Arab. 


\section{Lahn dalam Beberapa Ritual Ibadah}

\section{1- Lahn dalam adzan dan iqamah}

Hukum adzan dan iqamah adalah sunnah muakkad bagi shalat-shalat fardlu, walaupun shalat fardlu tersebut dilakukan munfarid (sendirian, tanpa berjama'ah), baik shalat fardlu itu adaa' (tepat waktu) maupun qadha' (di luar waktu), safar ataupun hadar (dalam perjalanan atau tidak). Kesunnahan ini khusus bagi laki-laki. Sedangkan bagi wanita, makruh hukumnya. Tidak mengumandangkan adzan dan iqamah sebelum shalat, hukumnya makruh tahriim dan disunnahkan mengulang bila meninggalkannya.

Korelasi antara tajwid dengan adzan dan iqamah sangat terkait sekali bila dilihat dari tata cara dan ketentuan hukum yang telah ditetapkan dalam syariat Islam. Lantunan adzan dianjurkan tarassul, yakni dengan irama pelan. dan jelas. Sedangkan iqamah dianjurkan agak cepat. Artikulasi (pengucapan) huruf-huruf yang terdapat dalam kalimat adzan dan iqamah juga harus benar dan sesuai dengan kaidah tajwid. Keharusan ini sama halnya dengan keharusan bertajwid saat membaca ayat suci al-Qur'an (Utsman, 1994: 302). Oleh sebab.itu, setiap huruf dalam kalimat adzan maupun iqamah harus diucapkan sesuai dengan makhraj huruf dan sifatnya.

Tentang mad atau panjang bacaan dalam adzan, ada perbedaan pendapat di antara madzhab fiqih. Mad terpanjang dalam adzan yang diperkenankan para ulama adalah 5 Alif (10 harakat): Pendapat lain menyatakan, 7 alif (14 harakat). Menambah atau mengurangi mad yang tidak semestinya (baca: lahn) pada saat melafalkan adzan atau iqamah, merupakan bagian dari hal-hal yang harus dihindari oleh muaddzin atau muquim.

Berikut ini beberapa kasus kesalahan yang sering dilakukan para muaddzin:

- Menambah mad melebihi batasan yang telah ditetapkan dalam kaidah ilmu tajwid, seperti saat mengucapkan mad liin pada huruf

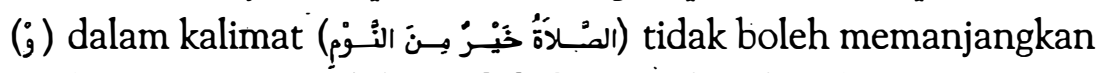
mad-nya wawu melebihi mad thabi'i (1 Alif/2 harakat).

- Menambah mad thabii pada alif lafadz jalalah (ل山l) ketika disambungdengan kata sesudahnya (i) jugatermasuk lahn (kesalahan). 
- Terlalu memanjangkan fathah sehingga melahirkan alif mad seperti

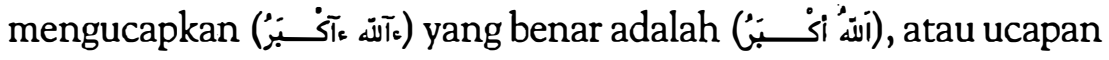

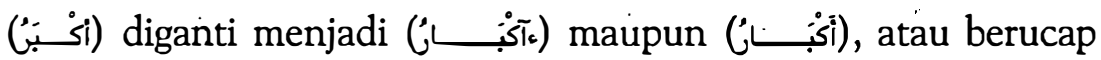

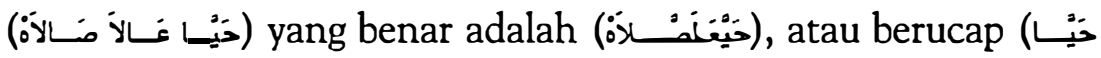

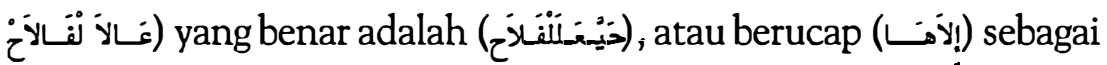
ganti dari (!ٕآة).

- Terlalu memanjangkan dhommah sehingga melahirkan mad baru,

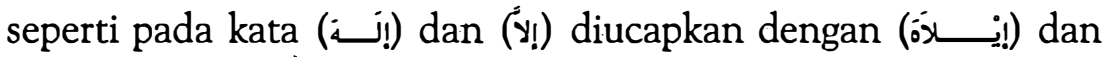
(إينـا).

- Penambahan beberapa hamzah dan alif, ketika muadzzin mengambil nafas pada saat mensuarakan mad, sehingga alif-nya terpotongpotong yang mengakibatkan muncul beberapa hamzah dan alif

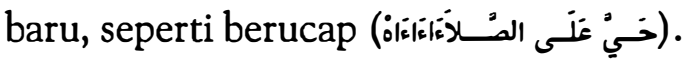

- Mengganti huruf ha' (ه) dengan (ح) sehingga kalimat yang seharus-

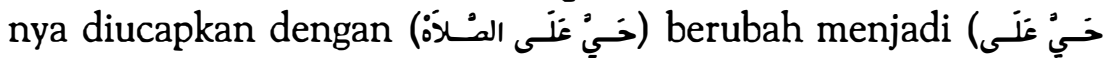

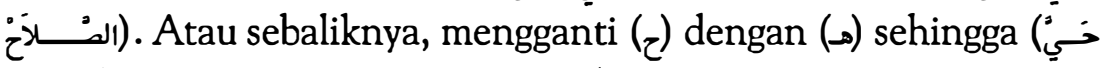

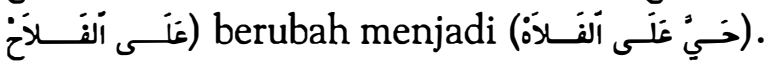

- Menggabungkan sebagian huruf dan kata dengan sebagian yang

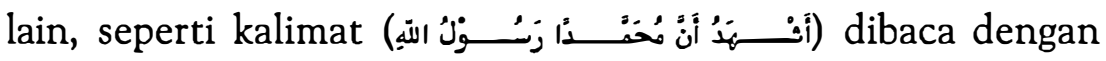

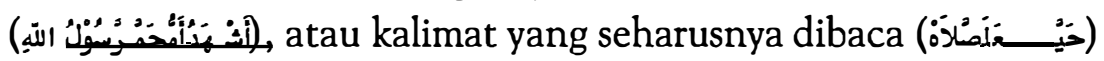

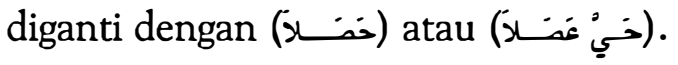

Selain contoh kesalahan dalam adzan seperti di atas, masih banyak lahn yang dilakukan seorang muaddzin atau muqiim yang notabene-nya sebagai orang yang mendirikan shalat dan seharusnya ia tidak membuat kesalahan (lahn). Kesalahan semacam ini harus dihindari.

\section{2- Lahn dalam takbir shalat}

Dalam syariat Islam, ditetapkan bahwa lafal takbiratul-ihram dalam

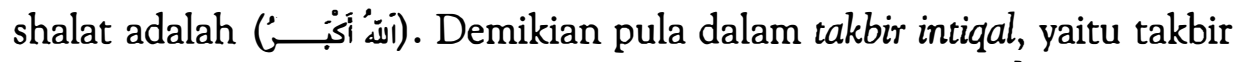
yang diucapkan saat berpindah dari satu rukun ke rukun yang lain, kecuali

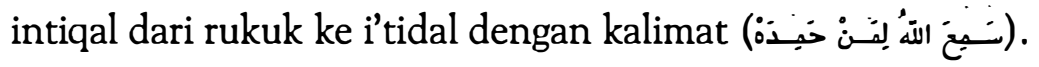


Seorang mushalli (shalat) harus membaca panjang alif dari lafadz jalalah (wil) seukuran (1 Alif/2 harakat) saja, tidak boleh lebih dan tidak boleh kurang, karena mad disini adalah mad thabii i: Akan tetapi sebagian musholli, terutama para miballigh yang berada di belakang imam, mereka seringkali menambah ukuran panjang alif pada lafadz jalalah saat mengucapkan (iأس

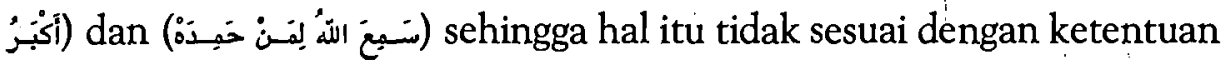
mad thabi'i.

Dalam takbir intiqal, ada lahn yang biasa dilakukan para imam. Yaitu, pada saat membaca lafadz jalalah ("ii), mereka membacanya dengan jahr (nyaring/keras) agar lafadz jalalah tersebut dapat didengar para makmum secara utuh. Namun, pada kata berikutnya, yaitu kata (i) mereka membacanya dengan siri (pelan), baik sebagian kata atau bahkan seluruhnya sehingga kata tersebut tidak terdengar secara utuh. Suara yang terdengar jelas dari imam hanya kata (آن), selebihnya hanya terdengar (ülil

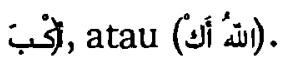

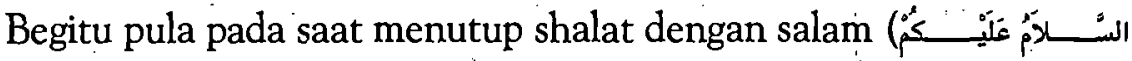

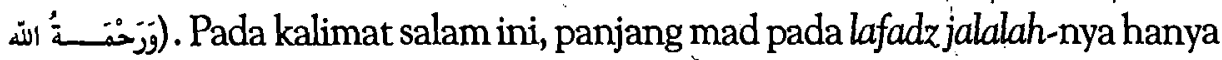
boleh dibaca satu, dua, ataupun tiga Alif (2/4/6 harakat) karena mad-nya adalah mad Aridh Lis-Sukuun yang dalam kaidah tajwid boleh dibaca qasr (pendek/1 alif), tawassuth (sedang/ 2 alif), atau thuul (panjang $/ 3$ alif). Akan tetapi, lahn (kesalahan) yang justru sering terjadi adalah seorang imam

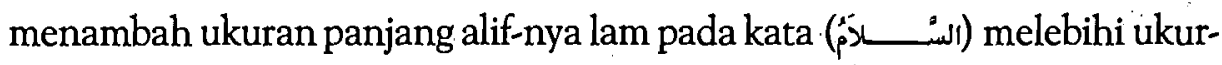
an 1 Alif ( 2 harakat), padahal mad (panjang) alif tersebut adalah mad thabi' $i$ yang ukurannya tidak boleh lebih dan tidak boleh kurang dari 1 Alif/2 harakat.

\section{3- Lahn dalam takbiran hari raya}

Takbiran yang identik dengan hari raya Idul Fitri dan Idul Adha disebut takbir muqayyad dan hukumnya sunnah muakkad. Lafal takbiran adalah sebagai berikut:

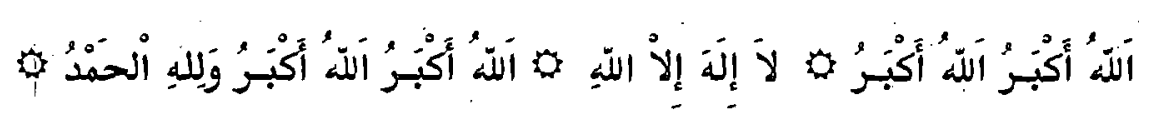


Lafal takbir tersebut boleh ditambah dengan beberapa dzikir yang lain, seperti:

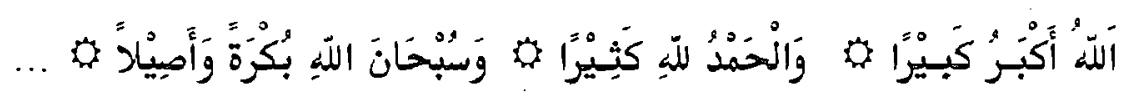

Dalam melafalkan takbir, menurut kaidah ilmu tajwid, huruf ra' dari takbir yang pertama dibaca dhammah, bila takbir pertama di-washal (disambung) dengan takbir kedua. Sedangkan ra' pada takbir kedua, disukun karena waqaf (berhenti). Ketentuan ini yang jarang diperhatikan pada saat takbiran di hari raya. Apalagi untuk takbiran yang sering diiringi tabuhan beduk atau rebana, bahkan alunan alat musik lainnya yang mengakibatkan orang yang sedang bertakbir terlena untuk mengikuti irama tabuhan atau musik, sementara ia tidak menghiraukan kaidah tajwid atau tata cara pengucapan yang benar.

Kasus lahn (kesalahan) yang umumnya terjadi pada saat takbiran

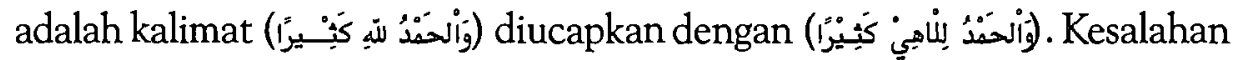
(lahn) ini dapat saja terjadi karena terlalu memanjangkan huruf ha' pada kata (u) sehingga melahirkan huruf baru yaitu ya'. Kesalahan semacam ini jelas merubah makna. Jadi, ia seakan memuji $a$ l-Lahi, padahal kata al-Lahi yang berarti lalai merupakan salah satu sifat setan.

\section{4- Lahn dalam talbiyah haji dan umrah}

Bagi jamaah haji dan umrah, disunnahkan sering bertalbiyah, terlebih lagi ketika usai berniat ihram haji dan umrah. (Depag RI, 1994:4) Kalimat talbiyah adalah:

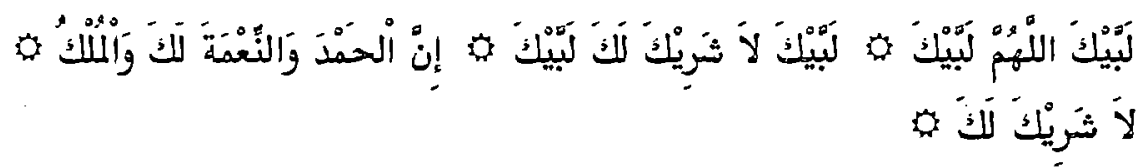
"Aku menyambut panggilan-Mu, Ya Allah. Aku menyambut panggilan-Mu. Aku menyambut panggilan-Mu yang tiada sekutu bagi-Mu. Sesungguhnya segala pujian, segala nikmat dan segala kerajaan hanyalah bagi-Mu. Tiada sekutu bagi-Mu".

Kesalahan (lahn) yang sering dilakukan jamaah haji pada saat membaca talbiyah terletak pada saat waqaf (bacaan berhenti) yang tidak 
pada tempatnya sehingga merubah makna. Misalnya, pada saat meng-

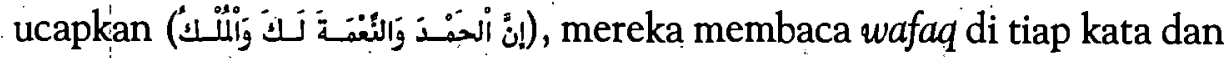
tetap men-fathah-kannya sehingga melahirkan alif mad yang baru. Contoh

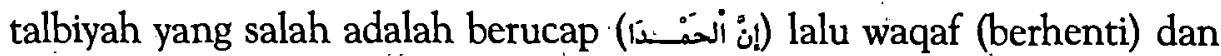
ditirukan oleh para jamaah lainnya. Kemudian membaca (gَ) lalu waqaf lagi dan ditirukan bersama, lantas memulai lagi (ibtida') dengan

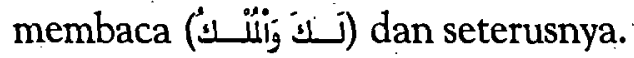

Dalam perspektif ilmu tajwid, membaca talbiyah seperti di atas termasuk lahn (salah) dengan alasan:

- Menghentikan bacaan atau waqaf yang pertama dan kedua pada contoh di atas adalah tidak diperbolehkan.

- Ibtida' (memulai bacaan kembali setelah waqaf) seperti itu juga salah.

- Memanjangkan fathah di setiap kata hingga melahirkan alif mad yang baru.

- Membaca ta' marbuthah saat wafaq kedua dengan suara ta', sedangkan yang benar, bila ta' marbuthah diwaqafkan, maka dibaca seperti ha'.

Contoh lahn (kesalahan) lain yang sering ditemukan pada jamaah haji yang sedang melakukan ibadah sa'i secara berkelompok, yaitu pada saat membaca ayat 157 surat al-Baqarah:

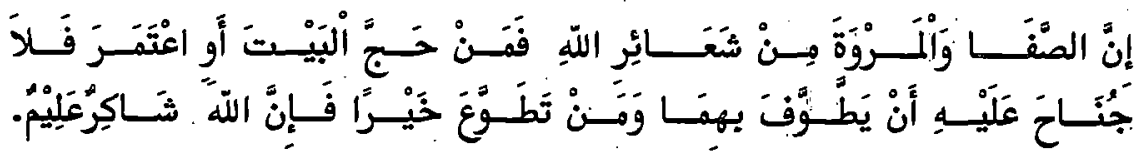

Dalam prakteknya, ayat di atas sering dibaca terputus-putus. Biasanya dilakukan oleh pimpinan rombongan haji yang bertugas mentalqin ayat agar ditirukan oleh para jamaahnya. Misalnya:

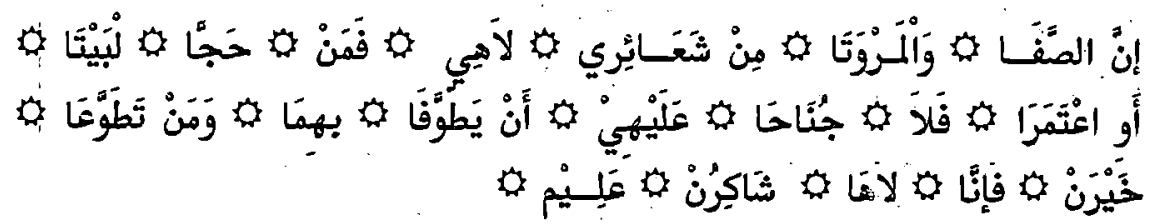


Cara membaca ayat secara terputus-putus seperti di atas, tidak bisa dibenarkan, sekalipun dengan alasan pembelajaran. Bacaan itu termasuk lahn (salah) itu karena terjadi pemotongan kata dengan waqaf ( yang salah dan tidak tepat sehingga maknanya berubah.

\section{5- Lahn dalam dzikir}

Bertajwid yang benar bukan hanya wajib pada saat membaca alQur'an saja, namun juga ketika berdzikir. Menyebut Asma Allah (ال山), huruf lam-nya harus tetap dibaca dengan mad thabii (1 Alif/2 harakat). At-Tijany (1963:221) menjelaskan bahwa para ulama telah menegaskan bahwa siapapun yang akan membaca wirid dari al-Qur'an, Asma', atau dari lainnya, ia harus terlebih dahulu memperbaiki makhraj dan sifat huruf.

Menurut penjelasan Al-Asyakh (Nasr, 130-131), kalimat dzikir ( إلــ huruf nafi ( $(y)$ boleh dibaca panjang maksimal 7 Alif/14 harakat dan lafadz jalalah (נل) dibaca 3 Alif/6 harakat. Akan tetapi, menurut Ibnu Jazari, diperbolehkannya membaca huruf nafi ( $y$ ) melebihi 3 Alif/6 harakat mengingat ia mad jaiz munfashil dan lafadz jalalah (נi) boleh dibaca 1 Alif/ 2 harakat mengingat ia hanya mad thabii, tidak lain karena fungsi nafi dan mad dalam dzikir adalah untuk mengagungkan Asma Allah SWT. Mad semacam ini disebut mad tadzim.

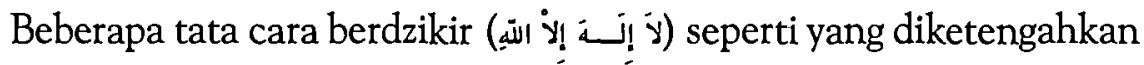
al-Jazari dan at-Tijany, antara lain:

- Pada saat berdzikir harus memanjangkan kata (ن) maksimal 7 Alif (14 harakat).

- Mentahqiq/membaca jelas huruf hamzah. (s) yang terdapat pada kata (إنـ ) dengan menfathah huruf ha'-nya (0) dengan fathah yang khafifah (ringan).

- Mensukun huruf akhir lafadz jalalah (ال山ّ).

- Pengucapan antara huruf ha dalam kata (إِــ tidak dipisah dengan

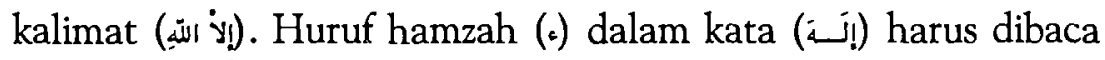
tahqiq (jelas) agar tidak berubah menjadi huruf ya', seperti: لاَ يَــلَّة) إlil). Kalimat seperti contoh ini bukan lagi disebut dzikir dan 
walaupun diulang berkali-kali tetap tidak mendapatkan pahala. Kesalahan (lahn) semacam ini kerap terjadi pada orang yang berdzikir.

Dengan demikian, berdzikir harus didasari dengan pengusaan ilmu tajwid yang baik dan benar agar dapat dicapai hasil dan tujuan yang sempurna.

\section{6- Lahn dalam tahlil dan tawassul}

Tahlilan berasal dari kata tahlil yang berarti: mengucapkan Laa Ilaaha Illallah (Munawwir, 1994:1615). Dinamakan tahlil karena para jamaah membacanya dengan berulang kali dengan jumlah banyak. Biasanya, tahlilan bertujuan untuk mendoakan ahli kubur dan lain sebagai-nya. Bacaanbacaan dalam acara tahlilan adalah rangkaian teratur yang disusun para wali dan ulama terdahulu, terdiri dari ayat al-Qur'an, shalawat, tasbih, Asmaul Husna, dan sebagainya.

Umumnya, urutan bacaan tahlil yang terdiri dari ayat-ayat suci alQuran adalah: surat al-Fatihah (tawassul), al-Ikhlas, al-Muawwidzatain, al-Fatihah, awal surat al-Baqarah ayat 1 sampai 5 , al-Baqarah ayat 163 , ayat kursi (al-Baqarah:255), akhir surat al-Baqarah ayat 284 sampai 286, dan seterusnya.

Dalam kajian ilmu tajwid, ada beberapa kasus lahn (kesalahan) dalam tahlilan yang harus dibenahi oleh para jamaah. Mereka seringkali tidak memperhatikan panjang mad thabi'i yang seharusnya cukup dibaca 1 Alif/ 2 harakat, sehingga mereka memanjangkannya melebihi ukuran yang telah ditetapkan dalam kaidah ilmu tajwid. Misalnya, ketika membaca ayat 286

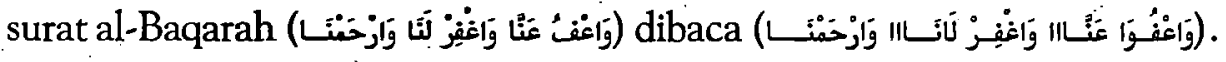

Selain itu, lahn (kesalahan) juga sering terjadi pada pembacaan surat al-Fatihah yang dibaca dengan cepat tanpa memperhatikan makhraj dan sifat huruf. Lahn dalam pembacaan surat al-Fatehah semacam ini, bukan hanya pada acara tahlilan atau ritual keagamaan saja, tapi juga pada pembukaan acara di even-even lain, seperti: acara peringatan maulid Nabi Muhammad SAW, peresmian masjid, wisuda dan sebagainya. Ironisnya, 
bacaan surat al-Fatihah tersebut justru dimaksudkan untuk tawassul yang pahalanya dihadiahkan bagi ahli kubur dan sebagainya. Padahal, sebuah bacaan yang salah, apalagi merubah makna, mengandung nilai dosa. Pertanyaan yang muncul dan patut direnungkan adalah: "Pahala ataukah justru dosa yang timbul dari bacaan surat al-Fatihah yang dibaca dengan salah itu yang akan dikirim ke ahli kubur?".

\section{7- Lahn dalam shalat}

Di dalam shalat, membaca surat al-Fatihah pada setiap raka'at merupakan salah satu rukun qauli yang harus dikerjakan. $\mathrm{Hal}$ ini berdasarkan hadis Nabi SAW (artinya): "Tidak sah shalat seseorang yang tidak membaca fathihah kitab". (HR. Bukhari-Muslim) Oleh karena itu, semua huruf dalam surat Al-Fatihah harus dibaca dengan benar dan tidak boleh terjadi lahn (kesalahan) yang menyebabkan perubahan makna. Bila terjadi lahn, maka shalatnya batal.

Membaca surat al-Fatihah harus memperhatikan hal-hal sebagai berikut:

- Tasydidnya yang berjumlah 14 harus dibaca semua, sebab huruf bertasydid mengandung 2 huruf. Jika salah satu tasydid tidak dibaca berarti menghilangkan satu huruf dan hal ini termasuk lahn (kesalahan) yang menyebabkan shalat tidak sah karena bacaan surat al-Fatihah belum sempurna.

- Huruf-hurufnya yang berjumlah 141 harus dibaca semua. Jika huruf yang bertasyid dihitung, surat al-Fatihah terdiri dari 155 huruf. Apabila satu huruf dihilangkan atau tidak terbaca, maka shalat tidak sah karena bacaan surat al-Fatihah belum sempurna.

- Membacanya dengan benar sesuai makhraj dan sifat huruf. Jika seseorang mampu membaca fasih atau dia tidak mampu tapi enggan untuk belajar, lalu pada saat membaca surat al-Fatihah, ia membaca huruf-hurufnya tidak sesuai dengan makhraj, seperti dha' (ض) dibaca dza' ( $(\dot{)})$, atau mengganti huruf dengan huruf lain yang dapat merubah arti, atau kata tersebut berubah menjadi sebuah kata yang tidak memiliki arti, seperti huruf (ح) pada (الحَّــد) diubah menjadi 
(ه), huruf (j) pada (الـذين) diubah menjadi (j) atau (د), atau dia membaca huruf dengan salah sehingga artinya berubah seperti:

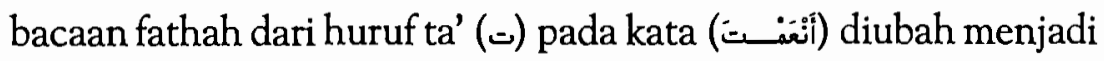
kasrah, atau bacaan fathah dari huruf kaf () pada kata (눈) diubah menjadi kasrah, semuanya itu menyebabkan bacaan surat al-Fatihah-nya menjadi batal dan hukum shalatnya juga tidak sah. Hukum ini berlaku bagi orang yang melakukannya dengan sengaja dan mengetahui bahwa hukumnya haram. Jika ia melakukannya tanpa unsur kesengajaan dan tidak mengetahui keharamannya, maka yang batal hanyalah bacaan al-Fatihah-nya, bukan shalatnya, sehingga ia harus mengulang bacaan al-Fatihah sebelum rukuk dan tidak berselang lama. Apabila ia terus melakukan rukuk sebelum mengulang atau membenarkan bacaan al-Fatihah yang salah, maka shalatnya batal. (Ad-Dimyati:140) Khusus bagi orang yang udzur, tidak bisa membaca fasih dan tidak mungkin untuk mempelajari tajwid dengan sempurna, maka bacaannya tidak dihukumi batal.

Lebih lanjut, Al-Malibary dalam kitabnya Fathul Mu'in menjelaskan, bahwa bagi orang yang mampu membaca dengan fasih atau ia tidak mampu lantaran ia enggan untuk belajar, maka:

- Jika ia menghilangkan tasydid suatu huruf, misalnya membaca

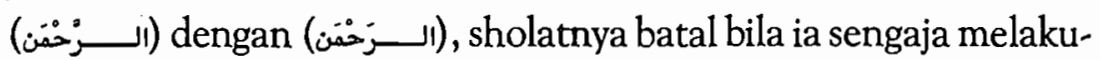
kan dan mengetahui akibat hukumnya. Kalau tidak, maka yang tidak sah hanya kalimat yang dibacanya itu.

- Jika ia menghilangkan tasydid pada (إيـــاك ) dengan sengaja dan memahami maknanya, ia dihukumi kafir sebab (إيَــاكـ tanpa tasydid berarti sinar matahari. Kalau tidak sengaja dan tidak tahu, ia cukup melakukan sujud sahwi.

- 'Jika seseorang mentasydidkan huruf yang tidak bertasydid, shalatnya tetap sah. Namun, hukumnya menjadi haram bila disengaja, seperti berhenti sebentar diantara huruf sin (w) dan ta' (ت) pada

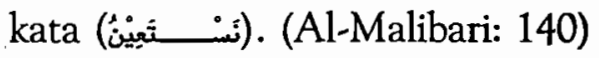




\section{8- Lahn dalam shalat jamaah}

Dalam sholat berjamaah, di antara syarat-syarat iqtida' (bermakmum) adalah seorang imam haruslah qari', yaitu orang yang mampu membaca al-Quran dengan baik dan benar sesuai dengan ketentuan tajwid. Seseorang tidak boleh bermakmum kepada orang yang ummi, yaitu orang yang buta huruf atau tidak mampu melafalkan dengan fasih. Terlebih lagi, seorang qari' tidak boleh bermakmum kepada orang ummi. Rasulullah SAW bersabda (artinya): "Yang berhak menjadi imam bagi suatu kaum adalah di antara mereka yang paling baik bacaannya". (Al-Husaini, 1994:10).

Termasuk dalam kategori orang ummi yang tidak boleh dijadikan imam, adalah:

1. Fasid (فاسـ); yaitu orang yang bacaan al-Fatihahnya tidak benar, baik keseluruhan maupun sebagian, ataupun hanya 1 (satu) huruf saja. (Ad-Dimyati: 43)

2. Arott (i); yaitu orang yang bacaannya bisa menyebabkan pergantian suatu huruf. Misalnya, ia mengidghamkan huruf yang tidak semestinya sehingga mengganti atau merubah redaksi kata,

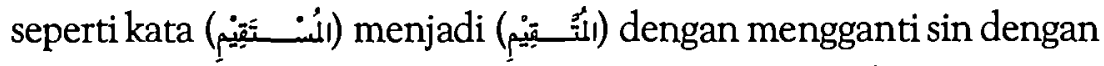
ta' karena idgham. Lain halnya dengan orang yang hanya mengindhomkan saja tanpa mengganti huruf, seperti mentasydid huruf lam atau kaf pada kata (مابـــ), maka ia bukan termasuk Arott.

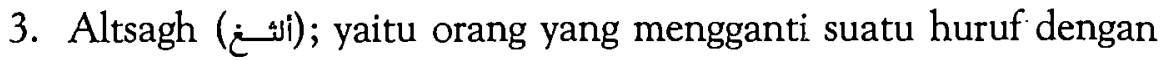
huruf lain (الإبـــــــال), baik pergantian huruf itu disertai idgham

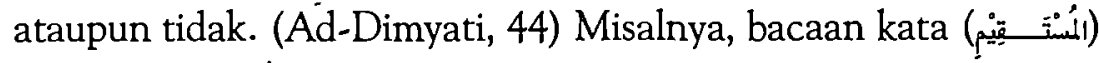

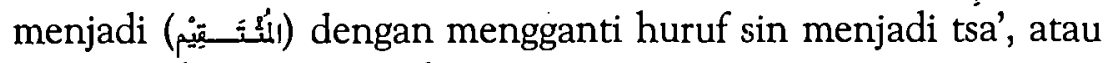

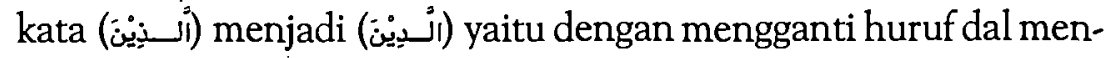
jadi dzal. (Al-Banteni, 1995:116) Jadi, pengertian Altsagh lebih umum daripada Arott.

4. Rakhwah (ل) (خوة); yaitu orang yang lisannya tidak dapat mengucapkan tasydiid. Ia tidak boleh menjadi imam. (Al-Husaini, 1994:110). 
Adapun seseorang bermakmum kepada orang yang ta-ta (bacaannya selalu mengulang-ulang ta') atau orang $f a^{\prime}-f a^{\prime}$ (bacaannya selalu mengulang fa) atau bermakmum kepada orang yang bacaannya salah (lahin) yang tidak sampai merubah arti, seperti membaca huruf ha pada kata (j) dengan

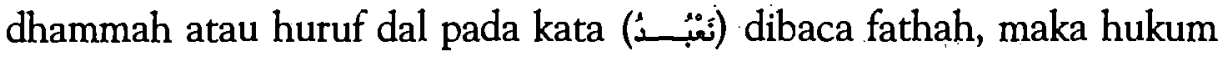
bermakmum kepada mereka adalah makruh.

Pada dasarnya, sebuah kesalahan (lahn) yang berakibat merubah makna seperti: membaca kasrah atau dhommah pada kata (أَنَفْــن yang seharusnya dibaca fathah, maka lahn semacam ini membatalkan shalat. Seseorang yang sering lahn (salah) dan ia masih mampu memperbaikinya tapi ia tidak mau belajar, maka shalatnya batal dan secara mutlak ia tidak boleh menjadi imam. Alasannya, kata yang diucapkan itu bukan lagi termasuk ayat suci al-Qur'an. Lain halnya dengan orang yang keadaannya tidak memungkinkan untuk memperbaiki bacaannya walaupun dengan belajar, maka sholatnya sah hanya untuk dirinya dan ia tidak berhak menjadi imam. Jika ada orang lain yang bermakmum kepadanya, maka shalat si makmum tidak sah. Kecuali, jika bacaan si makmum sama-sama lahn dengan imamnya, maka shalatnya tetap sah dan kasus ini termasuk dharurat. (AlBanteni, 1995:16)

Dengan demikian, makmum atau takmir masjid dituntut untuk selektif dalam memilih seorang imam. Jika makmum meragukan atau tidak mengetahui kemampuan imamnya, maka ia boleh tetap bermakmum kepada imam tersebut hanya pada shalat sirriyah (dhuhur dan ashar) saja. Jika makmum tetap mengikuti imam yang ia ketahui bacaannya lahn (salah) pada shalat jahriyah (subuh, maghrib dan isyak), maka si makmum harus mengulang shalatnya. (Al-Banteni, 1995:116)

\section{Kesimpulan}

Tạmpaknya fonologi Al-Qur'an memang harus dipelajari dan dikuasai setiap muslim mengingat implikasi yang diakibatkan lahn (kesalahan) dalam ujaran sangat luas hingga ke dalam berbagai aspek ritual ibadah. Pada beberapa ritual ibadah yang menggunakan bahasa Arab, dapat dipastikan munculnya lahn (kesalahan) yang biasanya dilakukan umat Islam, baik lahn jali maupun khafi. Perubahan makna karena kesalahan artikulasi yang 
menyimpang dari kaidah ilmu tajwid mengakibatkan sebuah ibadah tidak sempurna, bahkan tidak sah. Karenanya, sangat logis bila mempelajari ilmu tajwid hukumnya fardlu kifayah dan mengamalkannya menjadi fardlu ain yang wajib bagi setiap muslim.

Wallahu Alam

\section{Daftar Pustaka}

Abdurrahman bin Muhammad. tt. Bughyah al-Mustarsyidiin, Indonesia: Syirkah Nur Asia.

Ad-Dani, Usman bin Sa'id. 1988. at-Tahdiid Fii al-Itqaan wa at-Tajwïd, Baghdad: Dar el-Anbar.

Ad-Dimyati, Al-Bakri bin Syattha. tt. Hasyiyah 'Ianatuth Thalibiin, BairutLibanon: Daar el-Fikr.

Ad-Dimyati, Al-Bakri bin Syattha. tt. Hasyiyah 'Ianatuth Thalibiin, BairutLibanon: Daar el-Fikr.

Al-Banteni, Abu Abdul Mu'thi Muhammad bin Umar Al-Jawi. 1995. Nihayah az-Zain, Bairut-Libanon: Daar el-Fikr.

Al-Ghazali, Abu Hamid Muhammad bin Muhammad. 1991. Ihya Uluum ad-Din. Libanon: Dar el-Fikr.

Al-Habasi, Muhammad. 1987. Kaifa Nahfaz al-Qur'an. Bairut: Dar al-Khair. Al-Haitami, Ibnu Hajar. tt. Tuhfah al-Muhtaj, Istanbul-Turki: Maktabah alIslamiyah.

Al-Husaini, Taqiyyuddin Abu Bakar bin Muhammad. 1994. Kifayatul Akhyaar, Bairut-Libanon: Daar el-Fikr.

Al-Malibary, Zainuddin bin Abdul Aziz al-Fannany. tt. Fathul Mu'ïn Syarah Qurratul 'Ain Bi Muhimmat ad-Dïn, Bairut-Libanon: Daar elFikr.

Al-Qari, Abu Ashim Dr. Abdul Aziz bin Abdul Fattah. 1410 H. Qawaid at-Tajwid "Ala Riwayati Hafs An Ashim bin Abi an-Nujuud, Madinah: Maktabah al-Daar.

Alwi, Basori. 1993. Mabaadi' 'Ilmi at-Tajwiid, Malang: PIQ Singosari. 
Alwi, Muhammad Basori. 1993. Mabaadi fii Ilm at-Tajwid. Malang: PIQSingosari.

An-Nawawi, Yahya bin Syaraf ad-Diin. tt. Syarah Matan al-Arba'iin anNawawiyyah Fii al-Ahadiits an-Nabawiyyah; Bairut-Libanon: daar el-Fikr.

At-Tijany, Muhammad. 1963. Adillah Ahlis Sunnah Wal Jama'ah Fii Syatta al-Masa'il, Mesir: Maktabah Al-Qahirah.

- Depag RI, Wizaarah asy-Syu'un ad-Diniyyah Jumhuur Indonesia. 1994. Hikmah al-Hajj, Jakarta: Depag RI Dirjen Bimbingan Masyarakat Islam dan Urusan Haji.

Munawwir, Ahmad Warson. 1994. Kamus al-Munawwir Arab-Indonesia Terlengkap, Krapyak-Yogyakarta: Unit Pengadaan Bukubuku Ilmiah Ponpes al-Munawwir.

Nasr, Muhammad Makki. tt. Nihayah al-Qaul Al-Mufiid fii Ilm at-Tajwid. Kediri: al-Mahad al-Islamy as-Salafy Lirboyo.

Nasution, Ahmad Sayuti Anshari. 2006. Bunyi Bahasa. Jakarta: UIN Jakarta Press.

Taufiqurrochman. 2005. Metode Jibril. Malang: Ikapiq Singosari.

Utsman, Husni Syekh. 1994. Haq at-Tilawah. Jeddah: Dar el-Manarah.

Wahbah, Mahdy dan Kamil Muhandis. 1984. Mujam al-Mushthalahat alArabiyah fii al-Lughah al-Arabiyah. Bairut: Maktabah Lubnan. 